\title{
ANTIMICROBIAL RESISTANCE AND VIRULENCE GENES PROFILING OF PROTEUS SPECIES FROM POULTRY FARMS IN LAFIA, NIGERIA
}

\author{
Mojisola Christiana Owoseni $^{1 *}$, Odula Oyigye ${ }^{1}$, Bashiru Sani $^{1}$, Jebes Lamin $^{1,2}$, Amara Chere ${ }^{1}$ \\ ${ }^{1}$ Department of Microbiology, Federal University of Lafia, P.M.B. 146, Nasarawa State, Nigeria \\ ${ }^{2}$ Dalhatu-Araf Specialist Hospital, Lafia, Nasarawa State
}

*Corresponding author email: moji.owoseni@gmail.com | +2349034509990

\begin{abstract}
The poultry industry is important in boosting food sustainability of a population; however, the poultry environment and products are susceptible to pathogen contamination arising from poor farm hygienic conditions. This study investigated the prevalence, antimicrobial resistance and virulence profile of Proteus species from the environment and products of four selected poultry farms in Lafia, Nasarawa State. Farm samples $(\mathrm{n}=216)$ comprising feed (64), drinking water (64) and swabs from eggshells (88) were collected and analysed for detection of Proteus species using cultural, biochemical and microscopic techniques. Antibiotics susceptibilities of isolates were also determined, and virulence genes were confirmed using Polymerase Chain Reaction. Of the total studied samples, 34.26\% (74/216) were positive for Proteus species. Proteus species were more prevalent in drinking water samples $(37.84 \%)$ and feed samples $(33.78 \%)$ and least prevalent in eggshells $(28.38 \%)$. Proteus species $(\mathrm{n}=74)$ comprised P. mirabilis $78 \%(58 / 74)$ and Proteus vulgaris 22\% (16/74). P. mirabilis was markedly higher than $P$. vulgaris in all the four farms sampled. Farms A and D had the highest prevalence of Proteus species, while Farms A and C (80\%), and Farm D (25) has the highest prevalence of P. mirabilis and P. vulgaris respectively. The isolates' prevalence rate within and between farms, sample type, and species was not statistically significantly different $(\mathrm{p} \geq 0.05)$ from the other farms. Isolates were $100 \%$ susceptible to Amikacin and showed the highest resistance $(25.7 \%)$ to tetracycline. Molecular analysis of the virulence genes of Proteus species revealed the presence of $r s b A$, ureC and $\operatorname{luxS}$ virulent genes in all the test isolates. Data generated indicates a high level of multidrug-resistant pathogenic strains of Proteus circulating in poultry farms in Lafia, Nigeria, which potentiates a significant risk of transmission of pathogenic Proteus via the food chain.
\end{abstract}

Keywords: Food safety, Proteus species, virulence genes, antimicrobial resistance, poultry farms 


\section{Introduction}

The poultry industry is a major component of the Nigerian economy, providing a source of income to farmers and serving as a leading source of high-quality protein for the fast-growing population due to the affordability and acceptability of their products (Bettridge et al., 2014). However, the incidence of microbial infections from infected birds with clinical diseases in the poultry farm environment and products has threatened public health and food safety and may cripple economic gains derived from this industry (Foti et al., 2011; Menghistu et al., 2011).

Proteus poses a significant challenge to both humans and animals worldwide and is prevalent in several food and animals including poultry (Lei et al., 2014). There are now multiple resistant forms of this bacterium which indicates a major food issue (Lei et al., 2016). With several foodborne poisoning attributed to Proteus group of bacteria and rising incidence of Proteus induced foodborne infections, it is pertinent that control programs and prophylactic measurements be developed to prevent and combat outbreaks of foodborne infections/poisoning from poultry and poultry products (Ram et al., 2019). Poultry and other poultry products are believed to be the primary vehicle for the transmission of Proteus (Firildak et al., 2015). Poultry might have Proteus strains in their droppings and on their bodies (feathers, feet and beaks), even when they appear healthy and clean. The Proteus species can stick to cages, coops, feed and water dishes, hay, plants and soil in the area where the birds live; also eggshells may become contaminated with Proteus from poultry droppings (poop) or the area where they are laid (Jambalang et al., 2017). From a public health perspective, the number of eggs and animals affected by Proteus is a risk factor for human disease or infection (Awad-Alla et al., 2010).

Human cases of Proteus are typically acquired through the consumption of contaminated food. Proteus usually spread through the faecal-oral route (contamination of hands or objects with bacteria shed in the stool) (Tonkić et al., 2010). Proteus in chicken droppings might be transmitted to vulnerable workers while handling infected chicken directly or through faecalcontaminated poultry products (Barua et al., 2013; Lima-Filho et al., 2013). Generally, there are two possible routes of egg contamination by Proteus. Eggs can be contaminated by penetration of the bacterium through the eggshell from the colonised gut or from contaminated faeces during or after oviposition (horizontal transmission). Horizontal transmission occurs following ingestion 
of food or water already contaminated with faeces of clinically infected birds or carriers, presence of dead chickens, poultry farm attendants and contaminated feeds (Armbruster et al., 2014). The second possible route is by direct contamination of the yolk, albumen, eggshell membranes or eggshells before oviposition, originating from the infection of reproductive organs with Proteus (vertical transmission) (Momani et al., 2017; Moosavy et al., 2015).

Consumption of raw/undercooked eggs has consistently been identified as the primary risk factor for Proteus mirabilis (MD Salihu, 2015). Proteus is known to cause human urinary tract infection (UTI), nosocomial infection, wound infection (Ebringer and Rashid, 2014; Jacobsen et al., 2008) and showed clear history of zoonosis in vast host range with the emergence of multidrug resistance (MDR) in recent years (Tonkić et al., 2010). Multidrug-resistant Proteus may be transmitted among poultry farm workers who may transmit the pathogen in the surrounding environment.

Humans also use many classes of antimicrobial agents used in animals, and there is a potential selection and spread of antimicrobial-resistant bacteria or genes from animals to humans through the food chain (Food and Agriculture Organization (FAO), 2016). The indiscriminate use of antibiotics or congeners has created enormous pressure for the selection of antimicrobial resistance among bacterial pathogens worldwide, including Proteus strains found in poultry products and poultry environment (Nahar et al., 2014).

The virulence of the Proteus species is caused by several factors which are regulated and expressed by virulence genes encoded in operons (Kumar Trivedi, 2015; Pathirana et al., 2018). These virulence genes increase the pathogenicity of Proteus species among which include urease which is the most important enzyme for kidney and bladder stone formation (Mohamed et al., 2014) and enables it to produce an environment in which it can survive (Aboh et al., 2015). The luxS gene is involved in the synthesis of autoinducer 2 (AI-2) secreted by bacteria and used to communicate both the cell density and the metabolic potential of the environment (Badi and Sepahi, 2014). Swarming behaviour of $P$. mirabilis mediated by $r s b A$ gene has been associated with biofilm formation and extracellular polysaccharide formation (Różalski et al., 2012). Continuous monitoring and surveillance of poultry farms is pertinent to establish possible transmission routes of microbial pathogens from poultry farms via the food chain. 
This study investigated the prevalence, antimicrobial resistance and virulence gene profiles of Proteus species isolated from Poultry farm samples in Lafia, Nigeria.

\section{Material and Methods}

\subsection{Sample collection and bacterial isolation}

A cross-sectional study was conducted for two months between May and June 2019, and a total number of 216 samples from four commercial poultry farms in Lafia, Nasarawa State were collected. The sample size was determined by using the prevalence of $16.67 \%$ reported by (Esther Chat et al., 2019) and the following the equation described by (Naing et al., 2006) as

$$
n=\frac{Z^{2} P(1-P)}{d^{2}}
$$

Where: $\quad \mathrm{n}=$ sample size

$$
\begin{aligned}
& \mathrm{P}=\text { prevalence from a previous study }=16.67 \%=0.17 \\
& Z=\text { standard normal distribution at } 95 \% \text { confidence interval= } 1.96 . \\
& D=\text { absolute desired precision at } 5 \%=0.05 .
\end{aligned}
$$

Samples included poultry feed $(n=64)$, drinking water $(n=64)$ and unbroken eggshells $(n=88)$ from four selected poultry farms in equal amounts during early morning hours on a weekly interval. Swab samples collected from surfaces of eggshells were inoculated into buffered peptone water (BPW) (Oxoid, UK) in screw-capped bottles, incubated at $37{ }^{\circ} \mathrm{C}$ for $24 \mathrm{~h}$ and thereafter pre-enriched in Selenite-F broth. A loopful of culture from Selenite-F was sub-cultured by streaking onto Xylose lysine deoxycholate agar (XLD) and incubated at $37^{\circ} \mathrm{C}$ for $24 \mathrm{~h}$ (Office International des Epizooties (OIE), 2012; Suresh et al., 2006). One millilitre of poultry drinking trough was inoculated into $9 \mathrm{ml}$ of $\mathrm{BPW}$ and the mixture was incubated at $37^{\circ} \mathrm{C}$ for $24 \mathrm{~h}$. 
Thereafter, $1 \mathrm{ml}$ of the solution was transferred into $9 \mathrm{ml}$ Selenite-F broth and a loopful was streaked on XLD agar (Oxoid Basingstoke and Hampshire, UK) and incubated at $37^{\circ} \mathrm{C}$ for $24 \mathrm{~h}$.

\subsection{Identification of presumptive isolates}

Bacterial isolates were identified based on their cultural, biochemical, microscopic identification and morphological characteristics according to the method of Cheesbrough (Cheesbrough, 2006) and OIE (Office International des Epizooties (OIE), 2012). Isolates showing transparent colonies with black centre on XLD due to hydrogen sulphide production were selected as presumptive bacteria and subcultured on nutrient agar (Office International des Epizooties (OIE), 2012). Pure isolates were confirmed by their biochemical characteristics using urease, Triple sugar Iron test and citrate test. Afterwards, bacterial isolates identified as Proteus species were delineated into their various species by the indole test and stored on agar slants for further analysis.

\subsection{Antimicrobial susceptibility and resistance profiling of Proteus species}

The antimicrobial resistance profiles of Proteus species to ten antibiotics were determined by the disc diffusion method using standard procedures described by the Clinical Laboratory Standards Institute (CLSI) (CLSI, 2016). Ten commercial antibiotics disk (Oxoid, UK) which include:

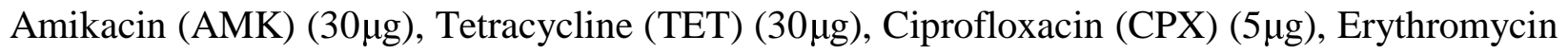

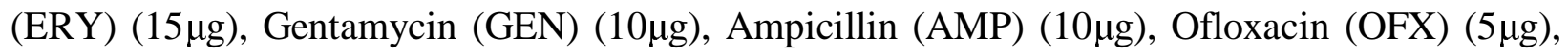

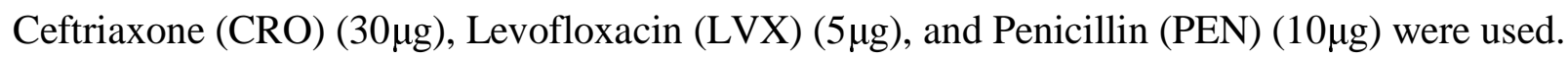

Bacterial species were spread on Mueller Hinton agar and antibiotics discs were aseptically placed on the plates using sterile forceps. Plates were incubated for $24 \mathrm{~h}$ at $37^{\circ} \mathrm{C}$. Thereafter, the diameters of the zones of inhibition were measured in millimetre $(\mathrm{mm})$ and results were 
interpreted using the Clinical Laboratory Standards Institute (CLSI) interpretative charts (CLSI, 2016).

\subsection{Molecular Identification of Virulence Genes of Proteus species}

\subsubsection{DNA extraction}

Genomic DNA was extracted using the boiling method. Briefly, $5 \mathrm{~mL}$ of bacterial isolates grown in Laura Bertani (LB) broth at $37^{\circ} \mathrm{C}$ for $8 \mathrm{~h}$ were centrifuged at $14000 \mathrm{rpm}$ for $3 \mathrm{~min}$. The cells were resuspended in $500 \mu \mathrm{l}$ of normal saline and heated at $95{ }^{\circ} \mathrm{C}$ for $20 \mathrm{~min}$ in the heating chamber. The heated bacterial suspension was cooled on ice and centrifuged at $14000 \mathrm{rpm}$ for 3 min. The supernatant containing the DNA was transferred to a $1.5 \mathrm{ml}$ microcentrifuge tubes and stored at $-20{ }^{\circ} \mathrm{C}$ for further use.

\subsubsection{DNA Quantification}

The extracted genomic DNA was quantified using the NanoDrop 1000 spectrophotometer by placing a drop (approximately $2 \mu \mathrm{l}$ ) on the sample space and analysed using the NanoDrop 1000 software.

\subsubsection{Molecular characterisation of virulence genes of Proteus species}

The virulence genes of Proteus species were characterised by Polymerase chain reaction technique. The following primer sets were used, (5' - TTGAAGGACGCGATCAGACC - 3') and (3' - ACTCTGCTGTCCTGTGGGTA- 5') which amplifies a 467 bp sequence of $r s b A$ gene (Abbas et al., 2015), (5' - ACTCTGCTGTCCTGTGGGTA -3') and (3' GTTATTCGTGATGGTATGGG-5') which amplifies the 317 bp sequence of ureC gene (Pathirana et al., 2018) and (5' - GTATGTCTGCACCTGCGGTA- 3') and (3' TTTGAGTTTGTCTTCTGGTAGTGC- 5') which amplifies the 464 bp sequence of luxS genes (Abbas et al., 2015). Gene amplification was carried out on thermal cycler (AB Biosystem, USA) 
at a final volume of $25 \mu 1$ for 35 cycles. The PCR mix included X2 Dream Taq Master Mix supplied by Inqaba, South Africa (Taq polymerase, dNTPs, $\mathrm{MgCl}$ ) and the primers at a concentration of $0.2 \mathrm{M}$ and $0.5 \mu \mathrm{LNA}$ as template. The PCR conditions were as follows: Initial denaturation, $95^{\circ} \mathrm{C}$ for 5 minutes; denaturation, $95^{\circ} \mathrm{C}$ for 30 seconds; annealing, $59^{\circ} \mathrm{C}$ for 30 seconds; extension, $72^{\circ} \mathrm{C}$ for 30 seconds for 35 cycles and final extension, $72^{\circ} \mathrm{C}$ for 5 minutes. The product was resolved on a $1 \%$ agarose gel at $120 \mathrm{~V}$ for 20 minutes and visualised on a UV transilluminator.

\section{Results}

\subsection{Identification of Proteus species}

Presumptive isolates were identified based on their cultural and biochemical characteristics. Cultural characteristics included transparent colonies with black centre on XLD due to hydrogen sulphide production. A total of 74 isolates were confirmed positive on urease media with the production of pinkish-red colouration of the medium. Further examination using Triple sugar Iron test showed black butt from hydrogen sulphide production $\left(\mathrm{H}_{2} \mathrm{~S}\right)$ while motility test produced a cloudy and distinct line of inoculation. Citrate test was positive for Proteus species. $P$. vulgaris was indole positive while $P$. mirabilis was indole negative.

The prevalence rate among the samples $(n=216)$ of eggshells $(88)$, poultry feed $(n=64)$, drinking water $(n=64)$ from the four poultry farms was $34.26 \%(74 / 216)$ (Table 1$)$. About a quarter 23.86\% (21/88) of eggshell swab samples were positive for Proteus while 39.06\% (25/64) and 43.75\% (28/64) of Feed and drinking water were positive for Proteus species respectively. Of the total 216 studied samples, Farm A and D had the highest prevalence rate of 9.26\% (20/216), followed by Farm B and Farm C with prevalence rates of 8.80\% (19/216) and 6.94\% (15/216) respectively. However, the prevalence of Proteus sp. did not vary significantly $(\mathrm{p} \leq 0.05)$ among all the samples collected from the four commercial farms. 
From the sample types, water from the trough contained the highest amount of Proteus species $37.84 \%(28 / 74)$, followed by the feed $33.78 \%(25 / 74)$, then the eggshell $28.38 \%(21 / 74)$ as shown in Figure 1.

Table 2 shows that $P$. mirabilis was more prevalent $78 \%(58 / 74)$ than $P$. vulgaris $21.6 \%(16 / 74)$ among all the samples from the four farms. The drinking water sample contained the highest prevalence of $P$. mirabilis $82 \%$ (23/28), followed by feed sample $76 \%(19 / 25)$ and eggshell sample $76 \%(16 / 25)$ while the feed and eggshell samples had the highest prevalence of $P$. vulgaris $24 \%(6 / 25$ and 5/21 respectively) and the lowest prevalence of $18 \%(5 / 28)$ was observed in drinking water samples. The prevalence of P. mirabilis was in the order; Farm A and C (80\%), Farms B (79\%) and Farm D (75\%) while P. vulgaris was in the other Farm D (25\%), followed by Farm B (21\%) and farms A and C (20).

Table 1. Prevalence of Proteus species from farm equipment and products from four commercial farms in Nasarawa State

\begin{tabular}{cccccc} 
Sample & \multicolumn{5}{c}{ Prevalence of positive samples (\%) } \\
\cline { 2 - 5 } type & Farm A & Farm B & Farm C & Farm D & $\begin{array}{c}\text { Total number of } \\
\text { positive samples (\%) }\end{array}$ \\
\hline $\begin{array}{c}\text { Eggshell } \\
\text { swabs } \\
(\mathrm{n}=22)\end{array}$ & $5(22.73)$ & $5(22.73)$ & $4(18.18)$ & $7(31.82)$ & $21 / 88(23.86)$ \\
$\begin{array}{c}\text { Feed } \\
(\mathrm{n}=16)\end{array}$ & $7(43.75)$ & $7(43.75)$ & $5(31.25)$ & $6(37.5)$ & $25 / 64(39.06)$ \\
$\begin{array}{c}\text { Drinking } \\
\text { water } \\
(\mathrm{n}=16)\end{array}$ & $8(50.00)$ & $7(43.75)$ & $6(37.5)$ & $7(43.75)$ & $28 / 64(43.75)$ \\
\hline $\begin{array}{c}\text { Total } \\
(\mathrm{n}=216)\end{array}$ & $20(9.26)$ & $19(8.80)$ & $15(6.94)$ & $20(9.26)$ & $74(34.26)$ \\
\hline
\end{tabular}




\section{Percentage prevalence of Proteus from studied sample type}

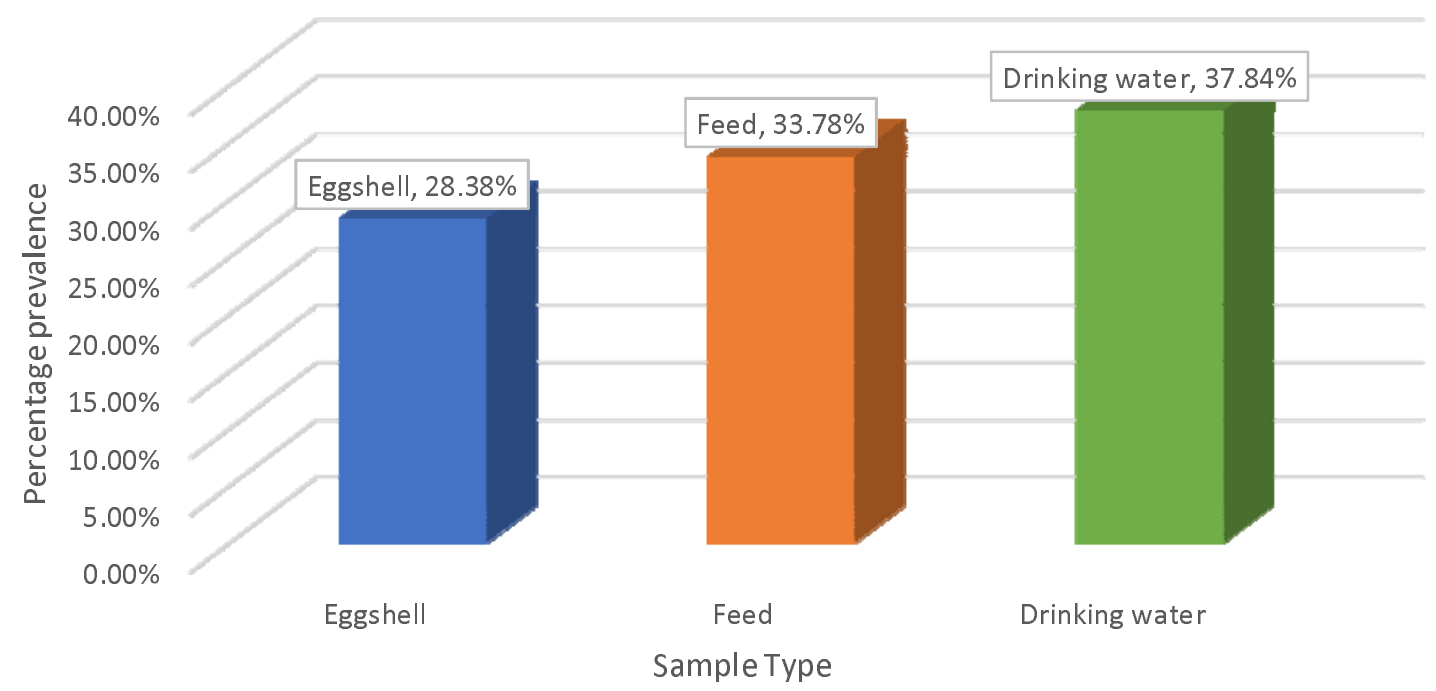

Fig 1: Percentage prevalence of Proteus species from the samples studied $(n=74)$

Table 2. Prevalence of $P$. mirabilis and $P$. vulgaris from four commercial farms in Nasarawa State

\begin{tabular}{|c|c|c|c|c|c|c|c|c|c|c|}
\hline \multirow{2}{*}{$\begin{array}{c}\text { Sample } \\
\text { type }\end{array}$} & \multicolumn{2}{|c|}{ Farm A } & \multicolumn{2}{|c|}{ Farm B } & \multicolumn{2}{|c|}{ Farm C } & \multicolumn{2}{|c|}{ Farm D } & \multicolumn{2}{|c|}{$\begin{array}{c}\text { Cumulative Total } \\
\text { across studied } \\
\text { farms }\end{array}$} \\
\hline & $P m(\%)$ & $P v(\%)$ & $P m(\%)$ & $P v(\%)$ & $P m(\%)$ & $P v(\%)$ & $P m(\%)$ & $P v(\%)$ & $P m(\%)$ & $P v(\%)$ \\
\hline Egg shell & $4 / 5(80)$ & $1 / 5(20)$ & $4 / 5(80)$ & $1 / 5(20)$ & $3 / 4(75)$ & $1 / 4(25)$ & $5 / 7(71)$ & 2/7 (29) & $\begin{array}{c}16 / 21 \\
(76)\end{array}$ & $\begin{array}{l}5 / 21 \\
(24)\end{array}$ \\
\hline Feed & $5 / 7(71)$ & 2/7 (29) & $6 / 7(86)$ & 1/7 (14) & $4 / 5(80)$ & $1 / 5(20)$ & $4 / 6(67)$ & $2 / 6(33)$ & $\begin{array}{c}19 / 25 \\
(76)\end{array}$ & $\begin{array}{l}6 / 25 \\
(24)\end{array}$ \\
\hline $\begin{array}{l}\text { Drinking } \\
\text { water }\end{array}$ & 7/8 (88) & $1 / 8(12)$ & $5 / 7(71)$ & 2/7 (29) & $5 / 6(83)$ & $1 / 6(17)$ & 6/7 (86) & 1/7 (14) & $\begin{array}{c}23 / 28 \\
(82)\end{array}$ & $\begin{array}{l}5 / 28 \\
(18)\end{array}$ \\
\hline $\begin{array}{l}\text { Total per } \\
\text { Proteus } \\
\text { sp }\end{array}$ & $\begin{array}{c}16 / 20 \\
(80)\end{array}$ & $\begin{array}{l}4 / 20 \\
(20)\end{array}$ & $\begin{array}{c}15 / 19 \\
(79)\end{array}$ & $\begin{array}{l}4 / 19 \\
(21)\end{array}$ & $\begin{array}{c}12 / 15 \\
(80)\end{array}$ & $\begin{array}{l}3 / 15 \\
(20)\end{array}$ & $\begin{array}{c}15 / 20 \\
(75)\end{array}$ & $5 / 20(25)$ & $\begin{array}{c}58 / 74 \\
(78)\end{array}$ & $\begin{array}{c}16 / 74 \\
(22)\end{array}$ \\
\hline
\end{tabular}


There was no significant statistical difference $(\mathrm{p} \geq 0.05)$ between and within the Proteus species, farms and sample type.

Key: Pm: Proteus mirabilis; Pv: Proteus vulgaris

\subsection{Antimicrobial susceptibility and resistance profiling of Proteus species}

As shown in Table 3, the antimicrobial susceptibility profile of the 74 confirmed Proteus species was tested against a panel of 10 antibiotics. Proteus species were susceptible to the antibiotics in varying amounts and susceptibility declined in the following order: Amikacin and Gentamicin (95.9\%), Levofloxacin (93.2\%), Ciprofloxacin and Penicillin (86.5\%), Ofloxacin (82.4\%), Erythromycin (81.1\%), Ampicillin (77.0\%) and Tetracycline (68.9\%). The resistance of Proteus to antibiotics was observed in the following order with the highest resistance recorded for tetracycline (25.7\%) followed by Erythromycin (13.5\%), Cefotaxime (12.2\%), Ampicillin (9.5\%), Ofloxacin and Penicillin (5.4\%), Gentamicin and Ciprofloxacin (4.1\%) and Levofloxacin

(1.4\%). No resistance was observed for Amikacin.


Table 3. Antimicrobial susceptibility profile of Proteus species in the four commercial poultry farms in Nasarawa State

\begin{tabular}{|c|c|c|c|c|c|c|c|c|c|}
\hline \multirow[b]{2}{*}{ Antibiotics ( $\mu \mathrm{g})$} & \multicolumn{3}{|c|}{ Susceptible } & \multicolumn{3}{|c|}{ Intermediate } & \multicolumn{3}{|c|}{ Resistant } \\
\hline & $\begin{array}{c}P . \\
\text { mirabilis } \\
(\%)\end{array}$ & $\begin{array}{c}P . \text { vulgaris } \\
(\%)\end{array}$ & Total & $\begin{array}{c}P . \text { mirabilis } \\
(\%)\end{array}$ & $\begin{array}{c}P . \text { vulgaris } \\
(\%)\end{array}$ & Total & $\begin{array}{c}P . \\
(\%)\end{array}$ & $\begin{array}{c}P . \text { vulgaris } \\
(\%)\end{array}$ & Total \\
\hline Amikacin (30) & $55(94.8)$ & $16(100)$ & 71(95.9) & $3(5.2)$ & $0(0)$ & $3(4.1)$ & 0 & $0(0)$ & $\mathbf{0}(\mathbf{0})$ \\
\hline Ciprofloxacin (5) & $54(93.1)$ & $10(62.5)$ & $64(86.5)$ & $3(5.2)$ & $5(31.3)$ & $8(10.8)$ & $0(0)$ & $2(12.5)$ & $3(4.1)$ \\
\hline Erythromycin (15) & $51(87.9)$ & $9(56.3)$ & $60(81.1)$ & $2(3.4)$ & $2(12.5)$ & $4(5.4)$ & $5(8.6)$ & $5(31.3)$ & $10(13.5)$ \\
\hline Tetracycline (30) & $45(77.6)$ & $6(37.5)$ & $51(68.9)$ & $4(6.9)$ & $0(0)$ & $4(5.4)$ & $9(15.5)$ & $10(62.5)$ & $19(25.7)$ \\
\hline Levofloxacin (5) & $53(91.4)$ & $16(100)$ & $69(93.2)$ & $4(6.9)$ & $1(6.3)$ & $5(6.8)$ & $1(1.7)$ & $0(0)$ & $1(1.4)$ \\
\hline Ofloxacin (5) & $53(91.4)$ & $8(50)$ & $61(82.4)$ & $3(5.2)$ & $6(37.5)$ & $9(12.2)$ & $3(5.2)$ & $1(6.3)$ & $4(5.4)$ \\
\hline Cefotaxime (30) & $48(82.3)$ & $11(68.8)$ & $59(79.7)$ & $4(6.9)$ & $2(12.5)$ & $6(8.1)$ & $6(10.3)$ & $3(18.8)$ & $9(12.2)$ \\
\hline Gentamicin (10) & $57(98.3)$ & $14(87.5)$ & 71(95.9) & $0(0)$ & $0(0)$ & $\mathbf{0}(\mathbf{0})$ & $2(3.4)$ & $1(6.3)$ & $3(4.1)$ \\
\hline Ampicillin (10) & $49(84.5)$ & $8(50)$ & $57(77.0)$ & $6(10.3)$ & $4(25.0)$ & $10(13.5)$ & $3(5.2)$ & $4(25.0)$ & $7(9.5)$ \\
\hline Penicillin (10) & $51(87.9)$ & $13(81.3)$ & $64(86.5)$ & $5(8.6)$ & $1(1.4)$ & $6(8.1)$ & $2(3.4)$ & $2(12.5)$ & $4(5.4)$ \\
\hline
\end{tabular}




\subsection{Molecular characterisation of virulence genes of bacterial species}

The molecular analysis of Proteus species was carried out to detect the virulence genes luxS, ure $C$ and $r s b A$ genes. Among the 15 Proteus species, the luxS gene was detected in seven Proteus isolates (four isolates of $P$. vulgaris and three isolates of $P$. mirabilis) (Figure 2). The ure $C$ gene was detected in ten Proteus isolates (six isolates of $P$. mirabilis isolates and four $P$. vulgaris isolates) (Figure 3) while the $r s b A$ gene was detected in four Proteus isolates (three $P$ mirabilis and one P. vulgaris isolates) (Figure 4).

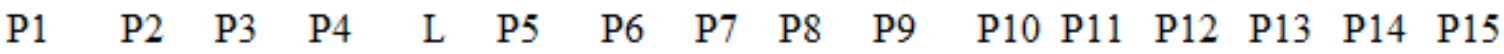

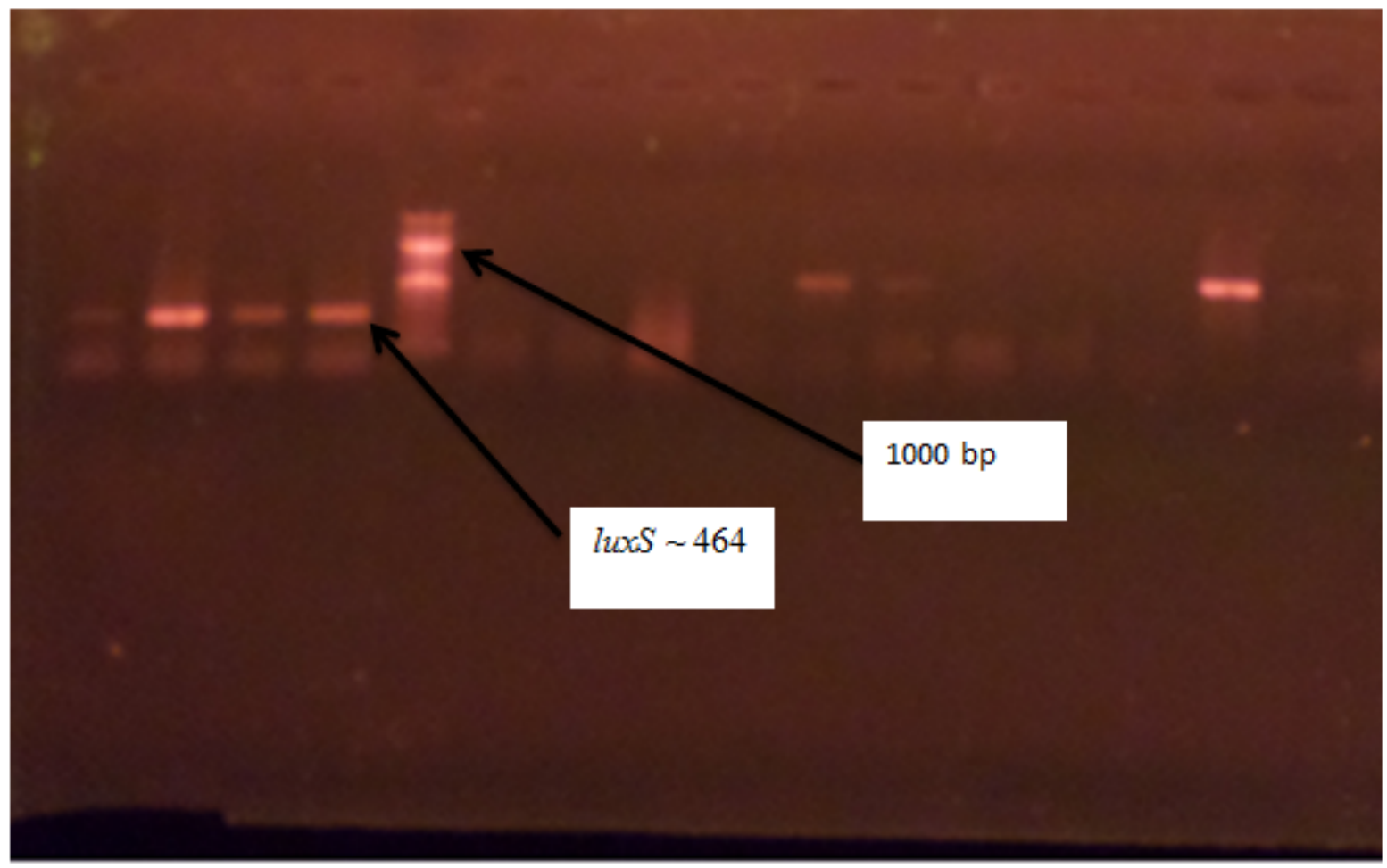

Figure 2: Agarose gel electrophoresis of the amplified luxS genes from the Proteus species. Lanes P1-P4, P9, P10 and P14 represent the luxS bands. Lane L represents the 1000 bp molecular ladder

Key: P1-P5 represent $P$. vulgaris; P6-P15 represent $P$. mirabilis. 


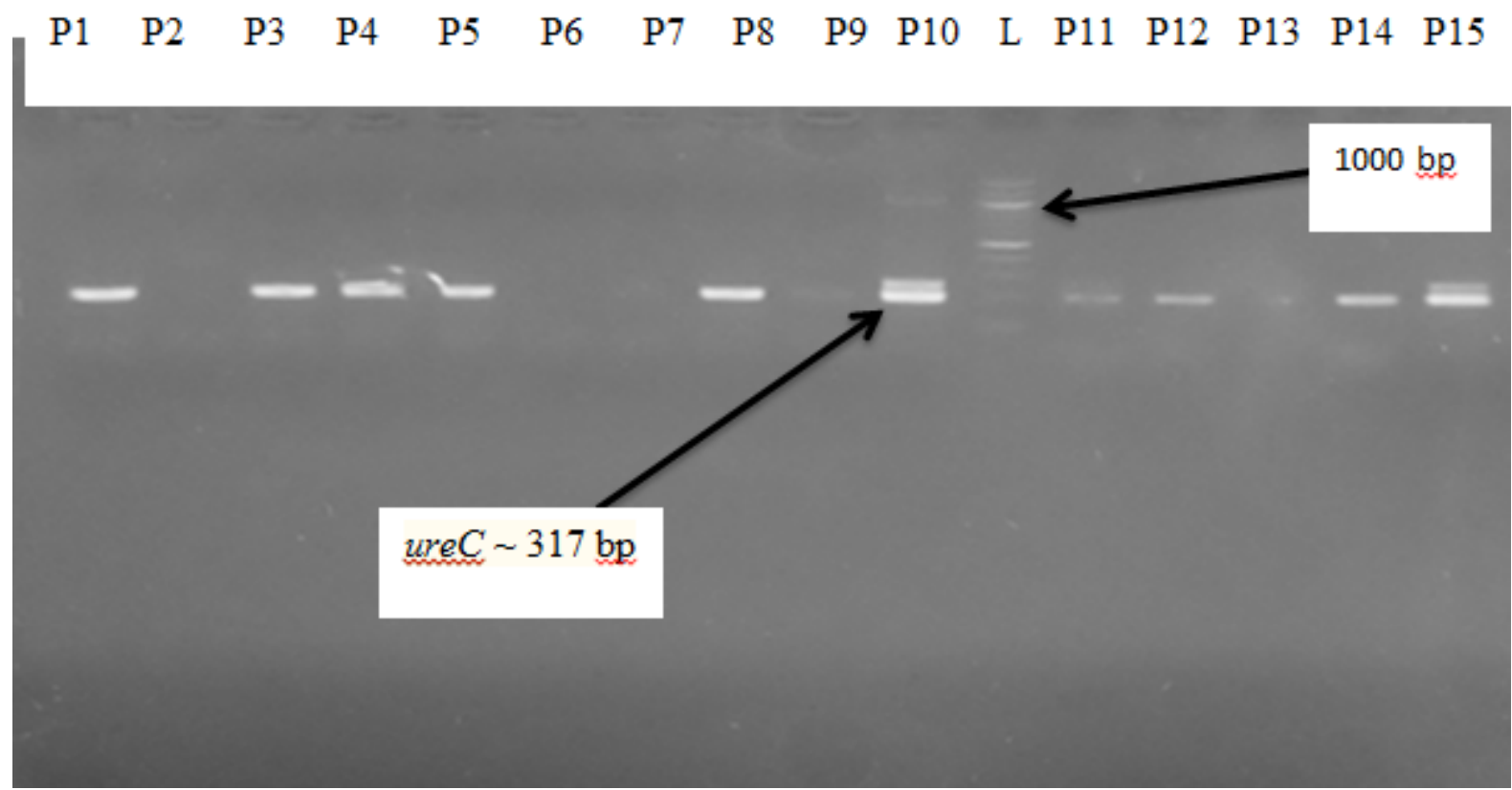

Figure 3: Agarose gel electrophoresis of the amplified ureC genes from the Proteus species. Lanes P1, P3-P5, P8, P10, P11, P12, P14 and P15 represent the ureC bands.

Lane L represents the 1000 bp molecular ladder, while other lanes show no band. Key: P1-P5 represent $P$. vulgaris; P6-P15 represent $P$. mirabilis.

$$
\begin{array}{lllllllllllllllll}
\text { P1 } & \text { P2 } & \text { P3 } & \text { P4 } & \text { P5 } & \text { P6 } & \text { L } & \text { P7 } & \text { P8 } & \text { P9 } & \text { P10 } & \text { P11 } & \text { P12 } & \text { P13 } & \text { P14 } & \text { P15 }
\end{array}
$$

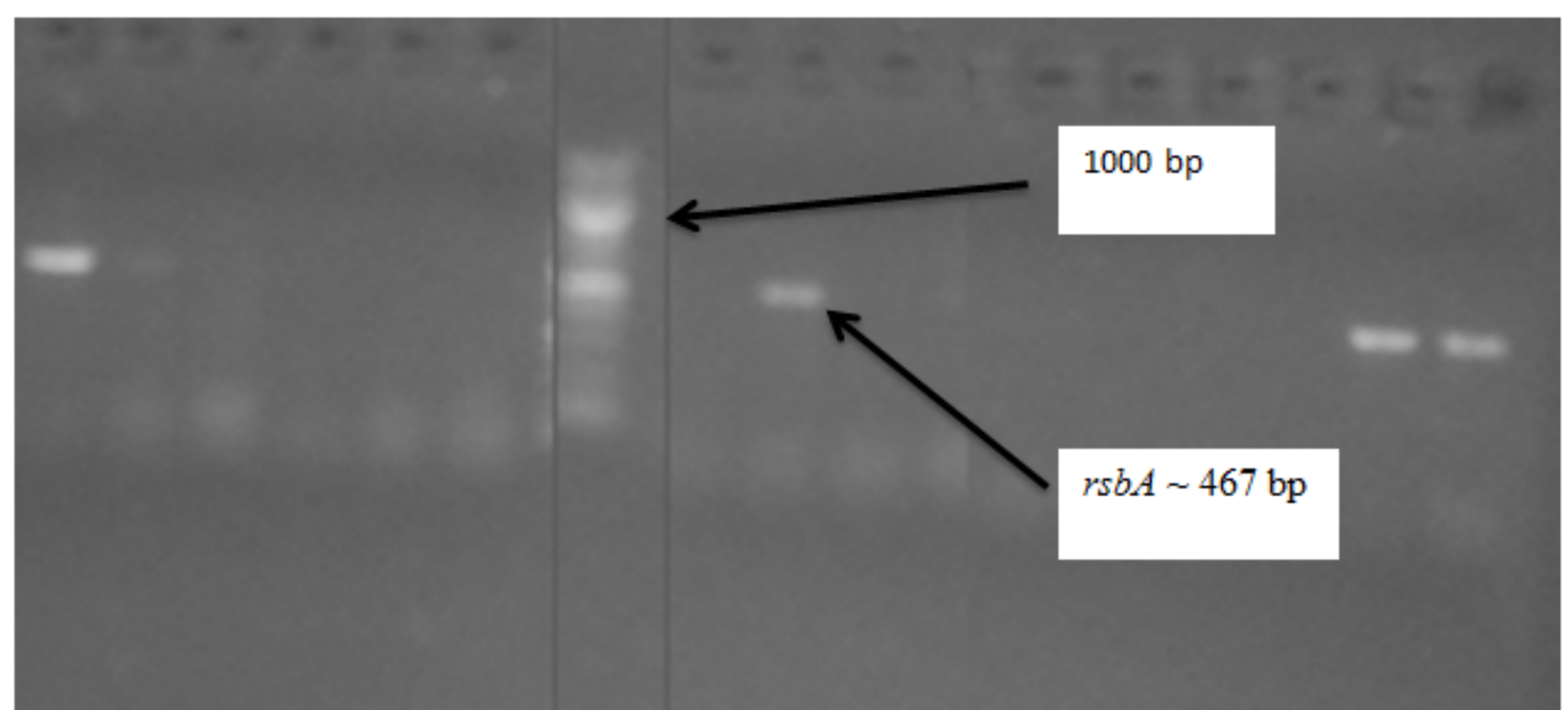

Figure 4: Agarose gel electrophoresis of the amplified $r s b A$ genes from the Proteus species. Lanes P1, P8, P14 and P15 represent the $r s b A$ bands.

Lane L represents the 1000 bp molecular ladder, while other lanes showed no band.

Key: P1-P5 represent $P$. vulgaris; P6-P15 represent $P$. mirabilis. 


\section{DISCUSSION}

The cross-sectional study examined the phenotypic resistance and virulence profile of Proteus species from eggshells, feed and drinking water samples collected from four commercial poultry farms in Lafia, Nasarawa State. The overall prevalence of Proteus species was approximately $34.3 \%$ (74 positive samples, $n=216$ ) with drinking water having the highest number of positive samples and $P$. mirabilis was the predominant species found in all the samples. Although the prevalence of Proteus species among all the samples from the four farms was not statistically significantly different $(\mathrm{P} \leq 0.05)$, the number of isolated Proteus species is still worrisome due to the ability of these bacterial pathogens to cause human infections such as pneumonia, septicaemia, central nervous system infection, food poisoning and urolithiasis (Barbour et al., 2012). Direct contact of humans with faecal droppings harbouring Proteus species can result in the transmission of the pathogens to immune-suppressed persons leading to urinary tract infections (Pathirana et al., 2018). P. mirabilis has been frequently isolated from chicken eggs, cloacal swabs and environmental samples from poultry farms. Ubiebi (Ubiebi, 2017) isolated $P$. mirabilis from poultry feeds in Delta State, Nigeria and P. mirabilis were among the isolates present in layers mash and broiler finisher samples obtained from ten poultry farms in Ekiti, Nigeria (Oyinloye et al., 2015). Enterobacteriaceae, including P. mirabilis and P. vulgaris, were frequently isolated from poultry birds (Kuznetsova et al., 2019).

Data generated from this study is of great public health importance as empirical evidence has demonstrated Proteus species' involvement in human diseases and as agents of animal infections and bacterial contamination of poultry products (Nahar et al., 2014). Additionally, the occurrence of Proteus species in these farms indicates defective biosafety measures in controlling rodents' infestations, insect vectors, wild birds and pet movements in the poultry pens.

The high prevalence of Proteus mirabilis $(78 \%)$ reported in this study is comparably higher to the prevalence of $66 \%$ documented by (Barbour et al., 2012). The highest prevalence of Proteus species, notably P. mirabilis, was recorded for farms A and C while Farm D had the lowest Proteus species' prevalence. This result could be attributed to poor sanitary practices in the farms such as lack of control of the entry of rodents and wild birds into the poultry houses, poor cleaning and disinfection of pens, and the citing of the two farms in waterlogged areas. On the other hand, Farm D was well fenced and good hygienic practices such as frequent cleaning of 
feed and water troughs were observed. Additionally, the entry of visitors into farm D is restricted in contrast to unrestricted visits to Farms A-C.

Antibiotics resistant bacteria were detected in all the four farm samples. The $25.7 \%$ resistance to Tetracycline in this study disagrees with the result of (Dadheech et al., 2015) who recorded a 100\% resistance of Proteus species isolated from chicken to Tetracycline in Ajmer Region, India. Data obtained may be attributed to tetracycline's frequent use in routine prophylaxis and chemotherapy in livestock management in Nigeria (Aliyu et al., 2019). The isolates also exhibited varying resistance to the other antibiotics such as Erythromycin (13.5\%) and Cefotaxime (12.2\%). This finding is baffling considering that Erythromycin and Cefotaxime are not routinely used in poultry management in the areas studied. This finding may suggest the transmission of Erythromycin and Cefotaxime resistant strains to the birds or contamination of eggs/water by poultry attendants in the farms. Antibiotics may be continuously administered as growth promoters to food-grade animals such as broilers and turkeys; therefore, the antibiotic selection pressure for resistance amongst bacteria in poultry is high and consequently their faecal flora contains a relatively high proportion of resistant bacteria (Nair et al., 2017). The interaction between the different components in a food chain or the environment further contributes to the spread of antibiotic resistance across species (Landers et al., 2012).

The most effective antibiotics against Proteus species were the Aminoglycosides, Amikacin and Gentamicin, with 95.9\% activity against Proteus while the highest resistance was recorded for tetracycline (25.7\%). Similar findings reported by (Kuznetsova et al., 2019) showed a low resistance of Proteus to Amikacin and Gentamicin and total resistance to tetracycline. The resistance of Proteus species to Ciprofloxacin (4.1\%) was low in this study compared to the report of Kuznetsova et al. (Kuznetsova et al., 2019) who recorded a 36.8\% resistance to Ciprofloxacin. The low level of resistance exhibited by the isolates to Ciprofloxacin may be attributed to the small size of the drug which is a factor that enhances its solubility in the diluents thus enhancing its penetration power through the cell into the cytoplasm of the target organism where it exerts its effects (Okpo et al., 2017). The high resistance of multidrug P. mirabilis to Tetracycline and its susceptibility to Ciprofloxacin in droppings of poultry birds collected in Bangladesh (Nahar et al., 2014) is consonance with the result obtained in our study where $P$. mirabilis was resistant to Tetracycline and sensitive to Ciprofloxacin. Okonko et al. (Okonko et 
al., 2010) found $P$. mirabilis to be $100 \%$ sensitive to streptomycin, an aminoglycoside in the same family with Amikacin and Gentamicin used in our study where the sensitivity was 95.9\%. Likewise, the resistant and susceptibility patterns of $P$. mirabilis to tetracycline and Gentamicin respectively were established in poultry feeds purchased from Calabar, Nigeria (Okonko et al., 2010). This report suggests that the presence of Proteus in poultry feeds may be attributed to commercially sold feeds contaminated with Proteus and not necessarily from poultry workers directly infecting the feed. In agreement with similar studies, the aminoglycosides seem to be the drug of choice to treat Proteus infections. The extra outer cytoplasmic membrane comprising the lipid bilayer, lipoproteins, polysaccharides and lipopolysaccharides may be responsible for Proteus resistance to antibiotics (Okonko et al., 2010). The availability and accessibility to antimicrobial compounds such as Ciprofloxacin, Streptomycin, Gentamicin, Erythromycin, Tetracycline, and Furazolidone among others in open markets to treat broiler/layer pose a challenge to reducing antimicrobial resistance in the poultry farms (Hasan et al., 2011; Nahar et al., 2014).

The ure $C$ gene was the predominant gene detected in this study. ure $C$ gene is responsible for the elevation of urine $\mathrm{pH}$, resulting in stone formation and it plays a crucial role in the virulence of Proteus species (Mohammed et al., 2014). Ram et al. (Ram et al., 2019) found ureC genes in the chicken cloacal swabs collected from a livestock farm complex in India. The frequency of occurrence of ureC genes (66.7\%) among the Proteus species was higher than the other two genes. However, the frequency of $66.7 \%$ is lower than similar findings of Pathirana et al. (Pathirana et al., 2018) who isolated Proteus species from humans and pet turtles and reported 91.7\% prevalence for ureC genes. Gene expression of ure $C$ genes and other virulent genes in Multidrug-resistant $P$. mirabilis isolated from diarrhetic animals in North-East China were associated with biofilm formation (Sun et al., 2020). The $r s b A$ gene was amplified in both $P$. mirabilis and P. vulgaris with a $26.7 \%$ frequency which is in contrast to the report of Abbas et al. (Abbas et al., 2015), who reported that $r s b A$ gene could not be amplified in P. mirabilis and $P$. vulgaris. Swarming behaviour of $P$. mirabilis is mediated by $r s b A$ gene, which may function as a protein sensor of environmental conditions (Różalski et al., 2012). The rsbA gene is also responsible for biofilm formation and extracellular polysaccharide formation (Różalski et al., 2012). The lux $\mathrm{S}$ genes were detected in all the Proteus species. luxS genes production has been 
implicated in biofilm formation by members of the Enterobacteriaceae, including Proteus species (Badi and Sepahi, 2014).

\section{CONCLUSIONS}

This study revealed the prevalence of antimicrobial-resistant Proteus species in poultry feed, water and eggshells collected from four poultry farms in Lafia, Nigeria. Proteus species were also confirmed to possess virulence genes suggestive of potential threat to food safety. To minimise the spread of antimicrobial resistance arising from poultry farms, it is vital to regulate the use of antimicrobial agents as growth promoters for poultry birds. Effective management of the poultry farm environment and farm products can also be achieved through routine monitoring and surveillance of farms to avert possible transmission of pathogenic microorganisms via the food chain. It is also a matter of urgency to ensure proper sanitation and hygiene in the farms by farm managers. Quality control of feeds purchased should be carried out to avoid transmission of pathogens from external sources. These measures will enable the check of pathogenic bacteria, including Proteus from poultry farms.

\section{Acknowledgement}

The authors hereby acknowledge Dr. Aliyu Yakubu (Department of Science Laboratory Technology, Federal Polytechnic Nasarawa) and the Department of Microbiology Laboratory's support staff, Federal University of Lafia for their support during the conduct of this study.

\section{Conflict of interest}

The authors declare that there is no conflict of interest.

\section{Funding source}

This research did not receive any specific grant from funding agencies in the public, commercial, or not-for-profit sectors. 


\section{References}

Abbas, K.F., Al Khafaji, J.K., Al-Shukri, M.S., 2015. Molecular Detection of Some Virulence Genes in Proteus Mirabilis Isolated from Hillaprovince. Int. J. Res. Stud. Biosci. 3, 85-89.

Aboh, E.A., Giwa, F.J., Giwa, A., 2015. Microbiological assessment of well waters in Samaru, Zaria, Kaduna, State, Nigeria. Ann. Afr. Med. 14, 32. https://doi.org/10.4103/15963519.148732

Aliyu, Y., Abdullahi, I.O., Whong, C.M.Z., Olayinka, B.O., 2019. Antibiotic resistant phenotypes of Staphylococcus aureus isolated from fresh and fermented milk in parts of Nasarawa State, Nigeria. African J. Microbiol. Res. 13, 446-456. https://doi.org/10.5897/ajmr2019.9175

Armbruster, C.E., Smith, S.N., Yep, A., Mobley, H.L.T., 2014. Increased incidence of urolithiasis and bacteremia during proteus mirabilis and providencia stuartii coinfection due to synergistic induction of urease activity. J. Infect. Dis. 209, 1524-1532. https://doi.org/10.1093/infdis/jit663

Awad-Alla, M.E., Abdien, H.M.F., Dessouki, A.A., 2010. Prevalence of bacteria and parasites in White Ibis in Egypt. Vet. Ital. 46, 277-86.

Badi, A.S., Sepahi, A.A., 2014. Detection luxS, qseC and rsbA genes' bands in Proteus mirabilis and Escherichia coli isolated from urinary tract infections, Pejouhandeh. Pajoohandeh Journal.

Barbour, E.K., Hajj, Z.G., Hamadeh, S., Shaib, H.A., Farran, M.T., Araj, G., Faroon, O., Barbour, K.E., Jirjis, F., Azhar, E., Kumosani, T., Harakeh, S., 2012. Comparison of phenotypic and virulence genes characteristics in human and chicken isolates of Proteus mirabilis. Pathog. Glob. Health 106, 352-357. https://doi.org/10.1179/2047773212Y.0000000042

Barua, H., Biswas, P.K., Olsen, K.E.P., Shil, S.K., Christensen, J.P., 2013. Molecular Characterisation of Motile Serovars of Salmonella enterica from Breeder and Commercial Broiler Poultry Farms in Bangladesh. PLoS One 8, e57811. https://doi.org/10.1371/journal.pone.0057811

Bettridge, J.M., Lynch, S.E., Brena, M.C., Melese, K., Dessie, T., Terfa, Z.G., Desta, T.T., Rushton, S., Hanotte, O., Kaiser, P., Wigley, P., Christley, R.M., 2014. Infectioninteractions in Ethiopian village chickens. Prev. Vet. Med. 117, 358-366. https://doi.org/10.1016/j.prevetmed.2014.07.002

Cheesbrough, M., 2006. District Laboratory Practice in Tropical Countries, Part 2 Second Edition. 
CLSI, 2016. Performance Standards for Antimicrobial Susceptibility Testing CLSI supplement M100S, Clinical and Laboratory Standards Institute, Wayne, PA.

Dadheech, T., Vyas, R., Rastog, V., 2015. Antibiotic resistance of aerobic bacterial isolates of Proteus mirabilis from sick layer chickens infected with septicaemia and salpingitis in Ajmer region of Rajasthan. World J. Pharm. Pharm. Sci. 4, 2002-2011.

Ebringer, A., Rashid, T., 2014. Rheumatoid arthritis is caused by a Proteus urinary tract infection. APMIS 122, 363-368. https://doi.org/10.1111/apm.12154

Esther Chat, M., John Dadah, A., Uba, A., 2019. Isolation of Enteric Bacteria from Various Sources in Selected Poultry Farms in Kaduna State. Bioprocess Eng. 3, 1. https://doi.org/10.11648/j.be.20190301.11

Firildak, G., Asan, A., Goren, E., 2015. Chicken Carcasses Bacterial Concentration at Poultry Slaughtering Facilities. Asian J. Biol. Sci. 8, 16-29. https://doi.org/10.3923/ajbs.2015.16.29

FOOD AND AGRICULTURE ORGANISATION (FAO), 2016. DRIVERS, DYNAMICS AND EPIDEMIOLOGY OF ANTIMICROBIAL RESISTANCE IN ANIMAL PRODUCTION. FAO.

Foti, M., Rinaldo, D., Guercio, A., Giacopello, C., Aleo, A., De Leo, F., Fisichella, V., Mammina, C., 2011. Pathogenic microorganisms carried by migratory birds passing through the territory of the island of Ustica, Sicily (Italy). Avian Pathol. 40, 405-409. https://doi.org/10.1080/03079457.2011.588940

Hasan, B., Faruque, R., Drobni, M., Waldenström, J., Sadique, A., Ahmed, K.U., Islam, Z., Parvez, M.B.H., Olsen, B., Alam, M., 2011. High Prevalence of Antibiotic Resistance in Pathogenic Escherichia coli from Large- and Small-Scale Poultry Farms in Bangladesh. Avian Dis. 55, 689-692. https://doi.org/10.1637/9686-021411-Reg.1

Jacobsen, S.M., Stickler, D.J., Mobley, H.L.T., Shirtliff, M.E., 2008. Complicated catheterassociated urinary tract infections due to Escherichia coli and Proteus mirabilis. Clin. Microbiol. Rev. https://doi.org/10.1128/CMR.00019-07

Jambalang, A.R., Buys, E.M., Botha, F.S., 2017. Bacterial species from retailed poultry eggs in Tshwane, South Africa: Implication for consumers. S. Afr. J. Sci. 113, 29-36.

Kumar Trivedi, M., 2015. Phenotyping and Genotyping Characterization of \&lt;i\&gt;Proteus vulgaris\&lt;/i\&gt; After Biofield Treatment. Int. J. Genet. Genomics 3, 66. https://doi.org/10.11648/j.ijgg.20150306.12

Kuznetsova, M.V., Afanasievskaya, E.V., Pokatilova, M.O., Kruglova, A.A., Gorovitz, E.S., 2019. Diversity and antibiotic resistance of enterobacteria isolated from boilers in a poultry farm of Perm Krai: A 14 -year study. Agric. Biol. 54, 754-766.

Landers, T.F., Cohen, B., Wittum, T.E., Larson, E.L., 2012. A review of antibiotic use in food animals: Perspective, policy, and potential. Public Health Rep. https://doi.org/10.1177/003335491212700103 
Lei, C.W., Zhang, A.Y., Liu, B.H., Wang, H.N., Guan, Z. Bin, Xu, C.W., Xia, Q.Q., Cheng, H., Zhang, D.D., 2014. Molecular characteristics of salmonella genomic island 1 in Proteus mirabilis isolates from poultry farms in China. Antimicrob. Agents Chemother. 58, 75707572. https://doi.org/10.1128/AAC.03992-14

Lei, C.W., Zhang, A.Y., Wang, H.N., Liu, B.H., Yang, L.Q., Yang, Y.Q., 2016. Characterisation of SXT/R391 integrative and conjugative elements in Proteus mirabilis isolates from foodproducing animals in China. Antimicrob. Agents Chemother. 60, 1935-1938. https://doi.org/10.1128/AAC.02852-15

Lima-Filho, J.V., Martins, L.V., Nascimento, D.C. de O., Ventura, R.F., Batista, J.E.C., Silva, A.F.B., Ralph, M.T., Vaz, R.V., Rabello, C.B.V., Silva, I. de M.M. da, Evêncio-Neto, J., 2013. Zoonotic potential of multidrug-resistant extraintestinal pathogenic Escherichia coli obtained from healthy poultry carcasses in Salvador, Brazil. Brazilian J. Infect. Dis. 17, 5461. https://doi.org/10.1016/j.bjid.2012.09.004

MD Salihu, B.G.\& Y.I., 2015. Evaluation of microbial contents of table eggs at retail outlets in Sokoto metropolis, Nigeria -. Sokoto J. Vet. Sci. 13, 22-28.

Menghistu, H.T., Rathore, R., Dhama, K., Agarwal, R.K., 2011. Isolation, Identification and Polymerase Chain Reaction (PCR) Detection of Salmonella Species from Field Materials of Poultry Origin. Int. J. Microbiol. Res. 2, 135-142.

Mohamed, T., Zhao, S., White, D.G., Parveen, S., 2014. Molecular characterisation of antibiotic resistant Salmonella Typhimurium and Salmonella Kentucky isolated from pre- and postchill whole broilers carcasses. Food Microbiol. 38, 6-15. https://doi.org/10.1016/j.fm.2013.08.002

Mohammed, S.O., Ahmed, E.S., Hafez, E.E., Khalid, A., Elshahaby, O.A., 2014. Characterisation and Purification of Urease Enzyme From New Proteus Mirabilis Strain. J. Adv. Sci. Res. 5, 8-11.

Momani, W. Al, Janakat, S., Khatatbeh, M., 2017. Bacterial contamination of table eggs sold in Jordanian markets. Pakistan J. Nutr. 17, 15-20. https://doi.org/10.3923/pjn.2018.15.20

Moosavy, M.-H., Esmaeili, S., Bagheri-Amiri, F., Mostafavi, E., Zahraei-Salehi, T., 2015. Detection of Salmonella spp in commercial eggs in Iran, Iranian Journal of Microbiology.

Nahar, A., Siddiquee, M., Nahar, S., Anwar, K.S., Ali, S.I., Islam, S., 2014. Multidrug ResistantProteus Mirabilis Isolated from Chicken Droppings in Commercial Poultry Farms: Biosecurity Concern and Emerging Public Health Threat in Bangladesh. J. Biosaf. Heal. Educ. 2,120 .

Naing, L., Winn, T., Rusli, B.N., 2006. Practical Issues in Calculating the Sample Size for Prevalence Studies, Archives of Orofacial Sciences.

Nair, M.S., Upadhyaya, I., Amalaradjou, M.A.R., Venkitanarayanan, K., 2017. Antimicrobial Food Additives and Disinfectants, in: Foodborne Pathogens and Antibiotic Resistance. John Wiley \& Sons, Inc., Hoboken, NJ, USA, pp. 275-301. 
https://doi.org/10.1002/9781119139188.ch12

Office International des Epizooties (OIE), 2012. MANUAL OF DIAGNOSTIC TESTS AND VACCINES FOR TERRESTRIAL ANIMALS, 7th ed. Paris.

Okonko, I., Nkang, A., Eyarefe, O., Abubakar, M., Ojezele, M., Amusan, T., 2010. Incidence of Multi-Drug Resistant (MDR) Organisms in Some Poultry Feeds Sold in Calabar Metropolis. Br. J. Pharmacol. Toxicol. 1, 15-28.

Okpo, N.., Abdullahi, I.., Whong, C.M.., Ameh, J.., 2017. Occurrence and antibiogram of Staphylococcus aureus in dairy products consumed in parts of Kaduna State, Nigeria. Bayero J. Pure Appl. Sci. 9, 225. https://doi.org/10.4314/bajopas.v9i2.39

Oyinloye, A., Amiolemhen, I., Ibitayo, A., 2015. (PDF) Antibiotic profile of some bacteria from poultry feed and Faeces in Ado Ekiti. J. Microbiol. Biotechnol. Res. 5.

Pathirana, H.N.K.S., De Silva, B.C.J., Wimalasena, S.H.M.P., Hossain, S., Heo, G.J., 2018. Comparison of virulence genes in Proteus species isolated from human and pet turtle. Iran. J. Vet. Res. 19, 48-52. https://doi.org/10.22099/ijvr.2018.4768

Ram, P., Rao, V., Rao, S., Subramanyam, K. V, Srinivas, K., 2019. Prevalence and virulence gene profiles of Proteus mirabilis isolated from animal, human and water samples in Krishna District, Andhra Pradesh, India. 19 Pharma Innov. J. 8, 19-23.

Różalski, A., Torzewska, A., Moryl, M., Kwil, I., Maszewska, A., Ostrowska, K., Drzewiecka, D., Zabłotni, A., Palusiak, A., Siwińska, M., Stączek, P., 2012. Proteus sp. - an opportunistic bacterial pathogen - classification, swarming growth, clinical significance and virulence factors. Folia Biol. Oecologica 8, 1-17. https://doi.org/10.2478/fobio-2013-0001

Sun, Y., Wen, S., Zhao, L., Xia, Q., Pan, Y., Liu, H., Wei, C., Chen, H., Ge, J., Wang, H., 2020. Association among biofilm formation, virulence gene expression, and antibiotic resistance in Proteus mirabilis isolates from diarrhetic animals in Northeast China. BMC Vet. Res. 16, 176. https://doi.org/10.1186/s12917-020-02372-w

Suresh, T., Hatha, A.A.M., Sreenivasan, D., Sangeetha, N., Lashmanaperumalsamy, P., 2006. Prevalence and antimicrobial resistance of Salmonella enteritidis and other salmonellas in the eggs and egg-storing trays from retails markets of Coimbatore, South India. Food Microbiol. 23, 294-299. https://doi.org/10.1016/j.fm.2005.04.001

Tonkić, M., Mohar, B., Šiško-Kraljević, K., Meško-Meglič, K., Goić-Barišić, I., Novak, A., Kovačić, A., Punda-Polić, V., 2010. High prevalence and molecular characterisation of extended-spectrum $\beta$-lactamase-producing Proteus mirabilis strains in southern Croatia. J. Med. Microbiol. 59, 1185-1190. https://doi.org/10.1099/jmm.0.016964-0

Ubiebi, C., 2017. ISOLATION AND IDENTIFICATION OF BACTERIAL ISOLATES FROM POULTRY AND FISH FEEDS SOLD IN ABRAKA, DELTA STATE, NIGERIA. J. Ind. Technol. 2. 
bioRxiv preprint doi: https://doi.org/10.1101/2021.01.07.425673; this version posted January 19, 2021. The copyright holder for this preprint (which was not certified by peer review) is the author/funder, who has granted bioRxiv a license to display the preprint in perpetuity. It is made available under aCC-BY-ND 4.0 International license. 